\title{
THE STRENGTHENING INNOVATION AND INFORMATION TECHNOLOGY CAPABILITIES IN VOCATIONAL SCHOOLS AS AN HRD ENTER POINT TO IMPROVE THE PERFORMANCE OF SMES
}

\author{
Iffah Budiningsih ${ }^{1, *}$, Tjiptogoro Dinarjo Soehari ${ }^{2}$, Fufung Alfulailah ${ }^{3}$ \\ ${ }^{1}$ Universitas Islam As-Syafi'iyah, Jl Raya Jatiwaringin No. 12 Pondok Gede, Jakarta Timur, 13077, Indonesia \\ ${ }^{2,3}$ Universitas Mercu Buana, Jl. Raya Meruya Selatan No. 1, Jakarta Barat, Indonesia \\ E-mail: Iffah budiningsih@uia.ac.id * \\ *Corresponding Author
}

\begin{abstract}
The purpose of this research is to show whether it is necessary to strengthen the capabilities of the innovation and informatics technology among vocational school students who will later become human resources enter points that can improve the performance of the SMEs industry in the digital era. We know that the SMEs industry is one of the pillars of Indonesia's economic development that spearheads job creators, and vocational graduates are expected to be the driving force for the achievement of SME optimal performance. This research relied on quantitative explanatory with survey method; its sample involved 176 out of 758 merchants (the total population) in Pasar Glodok Jakarta. All data were analyzed using descriptive and regression analysis with the SPSS program. The results showed that: (a) the ability innovating and the information technology of SME entrepreneurs is the dominant factor determining the achievement of optimal SME performance, with a correlation value $=0.79 .5$ or 0.8 (strong correlation); (b) Innovation and information technology skills contribute to the performance attainment of SME entrepreneurs in the research site by $63.2 \%$; the remaining $36.8 \%$ is determined by factors not included in the study; (c) Innovation and information technology capabilities are the capabilities needed by SMEs human resources in achieving optimal business performance; (d) it is necessary to strengthen the ability of innovation and information technology since school (especially Vocational schools) in a sustainable manner which will become the key point of SMEs industry's human resources as an effort to bring closer the concept of link and match between educational institutions and industry.
\end{abstract}

Keywords: business performance, information technology capabilities, innovation capabilities, SMEs, vocational schools

\section{INTRODUCTION}

Vocational Education (Vocational High School and Polytechnic or Diploma) is an education that prepares people who have certain skills to be ready to work in various industries or job markets. Vocational Education graduates are often considered by the industrial or labor market to have not met the required criteria to work (not ready for work). According to the data of Statistics Indonesia in 2021, the open unemployment rate in Indonesia derived from vocational graduates is still quite high, reaching $13.55 \%$ [1]. This shows that there has been no link and match between vocational education, industry and the labor market, it is suspected because there is no optimal harmonious communication between providers and labor users, such as the preparation of the curriculum is still running independently. The vocational education is slow to observe and respond to the needs of rapidly changing industries. The average curriculum change in educational institutions is conducted once every 3 (three) years, on the other hand, the change in the competence needs (hard and soft skills) vocational graduates to work changes very quickly (every 6 months or every year). This link and match gap causes the high unemployment rate of vocational education graduates.

The concept of link and match, in general, gives meaning to the need to describe the competencies of graduates needed in the future 
job market by educational institutions that can be used as a medium to increase the relevance of educational institution graduates to the needs of the workforce in the industry and labor market. Merdeka Belajar Kampus Merdeka (MBKM) program is a program to accelerate the realization of the concept of link and match between educational institutions and the industrial or labor market. By showing/publishing various research results from the industry (SMEs) about the competencies needed, it can provide input on strengthening any competence from vocational education graduates needed by industry (SMEs) as an entry point of human resources driving Indonesia's economic growth

\section{SMEs Industry}

Business in an era of very dynamic environmental change requires business people who are responsive and responsive to all rapid changes, such as the digital era, dynamic environmental changes, such as the case of the Covid 19 pandemic that generally collapsed almost all instruments of human life activities without exception activities in business. Changes in business activities are not easy to do, because it requires a careful planning process; to change is not easy, but it does not move, then the business will slowly perish. In the current digital landscape, small and medium enterprises, or henceforth SMEs, should create innovation that offers convenience and transparent processes in business transactions. The economic growth of a state is subject to the improvement of the businesspersons, regardless of level (i.e., small, medium-sized, and big business). According to the 2019 data by the Ministry of Cooperative and SMEs, $23.16 \%$ of the GDP was from the small, medium-sized, and big businesses; this trend was considered quite significant. On that ground, the contribution of SMEs to the state should not be underestimated. Each country has its definition of
SMEs. In Indonesia, a business is categorized SMEs based on several indicators, such as the volume of the business/turnover, net worth, numbers of the workforce, and initial capital, see Table 1 .

Table 1. Criteria of SMEs in Indonesia According to the Law Number 20 of 2008 Concerning SMEs

\begin{tabular}{cccc}
\hline \multirow{2}{*}{ No. } & Criterion & \multicolumn{2}{c}{ Level of Business } \\
\cline { 3 - 4 } & & Small Business & $\begin{array}{c}\text { Medium-Sized } \\
\text { Business }\end{array}$ \\
\hline 1 & Net worth & $\begin{array}{c}\text { >IDR 50 million to } \\
\text { IDR 500 million }\end{array}$ & $\begin{array}{c}\text { >IDR 500 } \\
\text { million to IDR } \\
10 \text { billion }\end{array}$ \\
& & & 20 to 99 \\
2 & Number of & 6 to 19 persons & persons \\
& Workforces & & Around IDR \\
3 & Initial capital & Around IDR 50 \\
& & million & 300 million \\
\hline
\end{tabular}

In Indonesia, the role of SMEs is considerably significant to economic growth SMEs contribute to (a) creating new jobs, (b) increasing GDP, and (c) providing safety nets in productive economic productivity. Therefore, many people favor SMEs, although the percentage of the contribution of this business to the GDP is quite low at $23.16 \%$ (2019). Reasons for people opting for SMEs involve the ease of adopting and implementing new technology in business and the growth and competitiveness of the business. The advantages of running an SME, such as (a) simple administration process, (b) implementing a lean management system, thus allowing effective coordination, (c) favoring managerial communication, (d) small numbers of workforces and (e) being flexible, capable of adjusting with market dynamics [2].

Pasar Glodok, the site of this research, is a popular wholesale in Jakarta. This market becomes one of the iconic spots in Indonesia, selling various electronics. Most of the merchants in the market are SME merchants. Based on the periodic observation results from 2018, Pasar Glodok was no longer flooded with customers 
compared to previous years. This trend has started since the emergence of business digitalization back in 2018 and has skyrocketed in recent days due to the COVID-19 pandemic in early 2020. As a result, many sellers have experienced a decline in sales and turnover, especially from the customer walking. The shift from face-to-face to digital marketing demands businesspersons to keep creating innovation and digitalization in business, particularly SMEs. This is to improve the business' performance attainment. Data from pre-research surveys on 35 sellers in Pasar Glodok report several issues, as seen in the following Table 2 .
Based on the survey results in Table 2, it is seen that people are unsure of the performance of their business without creating innovation and implementing IT. On that ground, exploring how innovation and IT skills correlate with business performance is essential. Are the two skills essential to the business performance of SMEs in Pasar Glodok? The present work aimed to find out the answer to this question since presumably, those two skills have a positive and significant correlation with the business performance variable.

Table 2. Results of Surveys on 35 Sellers in Pasar Glodok, Jakarta-Indonesia

\begin{tabular}{|c|c|c|c|c|}
\hline No & Statement & Factor & $\begin{array}{l}\text { Yes } \\
(\%)\end{array}$ & $\begin{array}{l}\text { No } \\
(\%)\end{array}$ \\
\hline 1 & I create/ improve my business & Innovation & $29 \%$ & $71 \%$ \\
\hline 2 & $\begin{array}{l}\text { Information technology or IT significantly } \\
\text { contributes to the improvement of my business }\end{array}$ & IT & $31 \%$ & $69 \%$ \\
\hline 3 & I am unsure whether or not my business will grow & Business performance & $60 \%$ & $40 \%$ \\
\hline 4 & $\begin{array}{l}\text { My business always sees an upward trend in its } \\
\text { turnover rate each year }\end{array}$ & Business performance & $40 \%$ & $60 \%$ \\
\hline
\end{tabular}

In general, the term "performance" can be defined as a specific ability that an individual or organization/company possesses to meet its goals by utilizing resources efficiently and effectively. Hernández \& Lerma [3] describe the business performance as the quantitative and qualitative outputs of a company in a specific period. Among the example of qualitative outputs are the evaluation results of the company from the client, while the quantitative outputs include the profitability evaluation results. Obtaining qualitative and quantitative business performance data from SMEs is a complex process compared to retrieving the same data from big companies going public. Zulkiffli \& Perera [4] state that SME managers often decline to provide accurate and objective performance data to the revenue officers, researchers, and other authorities. Although the companies have objective data, those data do not represent the actual business performance since data manipulation is performed to avoid taxes. SME managers tend to submit subjective data to prevent data leakage (not transparent) as the business is yet going public. As a result, the business performance is mostly assessed qualitatively by taking into account the testimony of clients, consumers, and other involved stakeholders. Some of the above arguments imply the necessity to incorporate innovation and technology in the business management of SMEs. Otherwise, the business will go down a rocky road.

According to Nimlaor et al. [5], it is easier to improve SMEs' performance through business alliances, strengthening networks and clusters for bargaining power among SMEs, and innovative sustainable development for enhancing production and operation efficiency. Although distinguishing the concept of performance and productivity is a complicated process, Khan et al. 
[6] specify the difference between the two: productivity refers to the temporary workload in a specific time, while performance is a broader concept encompassing consistency, productivity, and quality. Simply put, business consistency, productivity, and quality can be regarded as the indicator of the business performance of SMEs. Sudiarta et al. [7] claim that internal and external factors of SMEs are central to the business performance; the internal factors cover (a) human resource quality, (b) management, organizational and technical skills, (c) entrepreneurship competencies, (d) capital and market information access, (e) other production input factors, and (f) business innovation. The external factors include (a) social network, (b) legality, (c) government support (including technology workshop and access to information).

From the above discussion, the term SMEs performance, in the context of the present work, refers to the ability of a company to meet its goals by utilizing all resources the company has efficiently and effectively. The performance is reflected in the company's consistency, productivity, and quality.

\section{Innovation Skills}

Competitive and market globalization pressure has a positive implication to business through encouragement to all business levels, i.e., small, medium-sized, and big, to create innovation. In general, SMEs practice a pragmatic approach and are profit-oriented. As a result, oftentimes the business ignores the basic principle for sustainability and consistency in its performance, particularly in innovative culture development. According to Oza \& Mehta [8], the term ability is generally described as the attribute underpinning mental abilities that control how an individual interacts with the world. Bahador and Haider [9] further explain the concept of ability as having adequate capacities in aspects, such as skills and knowledge. Competencies are often associated with employees' $\mathrm{s}$ skills and requirements that a worker should meet. According to Irlandia as cited in Fauziah et al. [10], innovation means creating commercial products through the invention or creative process, development, and completely new processes. This idea elaborates that innovation is the function of entrepreneurship of an individual or group, business organization, and public or government services.

Innovation is necessary for the current competitive business atmosphere, including SMEs. An organization is considered innovative if it has created something different, i.e., finding a new area of business, taking risks, creating a breakthrough. SMEs that have created innovation successfully ware one level above the majority of the same business in terms of generating new ideas systematically in managing unique business compared to others. Consequently, the business reaches an optimum level of success. Innovation is of paramount importance in ensuring long-term success in a dynamic market [6]. There are three stages of innovative behavior of an individual Carmeli \& Spreitzer [11]. First stage is identifying the problem before formulating solutions and new ideas. Second stage is looking for methods to promote solutions or ideas to develop legitimacy and to gain support from the internal and external of an organization. Third stage is implementing the ideas into work, i.e., producing an applicable prototype innovation model capable of boosting the performance of an organization.

Budiningsih et al. [12] explained that the ability of innovation is efforts made to find, produce, introduce and apply a new finding in the form of ideas and solutions, technology that is useful for every human activity/ business indicated to be: looking/ seeing opportunities/ opportunities, building/ issuing ideas, seeking support for implementation and realizing/ 
applying new ideas. Andri et al. [13] claim that innovative behavior is an output of productive idea development to enhance processes, procedures, and products. According to Budiningsih et al. [14], regarding innovation, technology literacy has no significant contribution to the process of instilling innovative behavior in entrepreneur candidates. From this notion, one can say that technology is not an absolute prerequisite of innovation. Tidd and Bessant [15] mention several types of business innovation: (a) product innovation (what products should be offered), (b) process innovation (how the process and offer goes), (c) position innovation (market target), and (d) paradigm innovation (how the concepts should be framed).

In conclusion, the innovation skills of SMEs refer to efforts in finding out, producing, introducing, and applying something new, e.g., ideas and solutions, or technology that are impactful to the business activities; the activities revolve around (a) product innovation, (b) process innovation, (c) position innovation, and (d) paradigm innovation.

\section{IT Skills}

Over the development of technology, business, and industries, regardless its levels, have familiarized themselves with technology in their management process. Almost all business activities have been automatized due to IT because this aspect has been an integral part of business performance. SMEs generally rely on local resources, and they are not an importdependence business. As a result, the superior products of SMEs have their uniqueness, thus holding export potentials. Boosting the performance of SMEs is of paramount importance, given their significant contribution to economic growth. Doing so enables businesses to compete in today's globalized world.
Cultivating SMEs' competitiveness can be done by the implementation of IT, such as (a) broadening market network and market share, (b) improving accuracy and efficiency of marketing, and (c) enhancing information exchange and business transformation. SMEs are demanded to start incorporating IT and other digital technologies in their business management. A study by Roosdhani [16] reports that some SMEs in several parts of Indonesia have yet to implement IT effectively, despite the eagerness of the businesses to use technology.

United Nations [17] lists the indicators of a company or individual with technology awareness: (a) keeping up with the technology development, (b) comprehending the application and limitation of technology, (c) striving to actively apply appropriate technology for a specific task, and (d) willing to learn new technology. Bahador \& Haider [9] explained that IT skills are significant for SMEs; these skills cover: (a) the utilization of IT, (b) experience in handling IT-related problems, and (c) management of the IT concepts. Recently, almost all businesses have been automatized as technology has been an integral part of business activities. IT skills are of significant importance for all business levels. Lo'pez \& Alegre [18] classify three concepts of IT, namely (a) IT knowledge (demonstrating flexibility to adapt with the market potential), (b) IT operational (methods, processes, and techniques of IT possibly required), (c) IT infrastructures (artifacts, devices, and resources possibly needed for access, process, storage, distribution, and utilization of technology). Further, Lo'pez \& Alegre [18] argue that IT skills are impactful to business performance through knowledge management mediation. From the above discussion, it is clear that the IT skills of SMEs cover the aspects of IT knowledge, IT operations, and IT infrastructures. 


\section{METHOD}

The present work relied on a quantitative method with a survey. It aimed at determining the impact of independent variables, namely innovation skills $\left(\mathrm{X}_{1}\right)$ and IT skills $\left(\mathrm{X}_{2}\right)$, on the dependent variable, i.e., the performance of SMEs (Y). A total of 176 out of 758 merchant populations in Pasar Glodok, Jakarta, were randomly selected as the research respondents. The data were collected from a Likert scale; the scale comprises: strongly agree (score 5), agree (score 4), neither agree nor disagree (score 3), disagree (score 2), and strongly disagree (score 1). The indicator of research variables, as mentioned previously, were displayed in Table 3. Results of validity and reliability tests of each instrument of the variable $\left(\mathrm{Y}, \mathrm{X}_{1}\right.$, and $\left.\mathrm{X}_{2}\right)$ are provided in Table 4.

Table 3. Variable, Indicator, and Sub-Indicator of Research

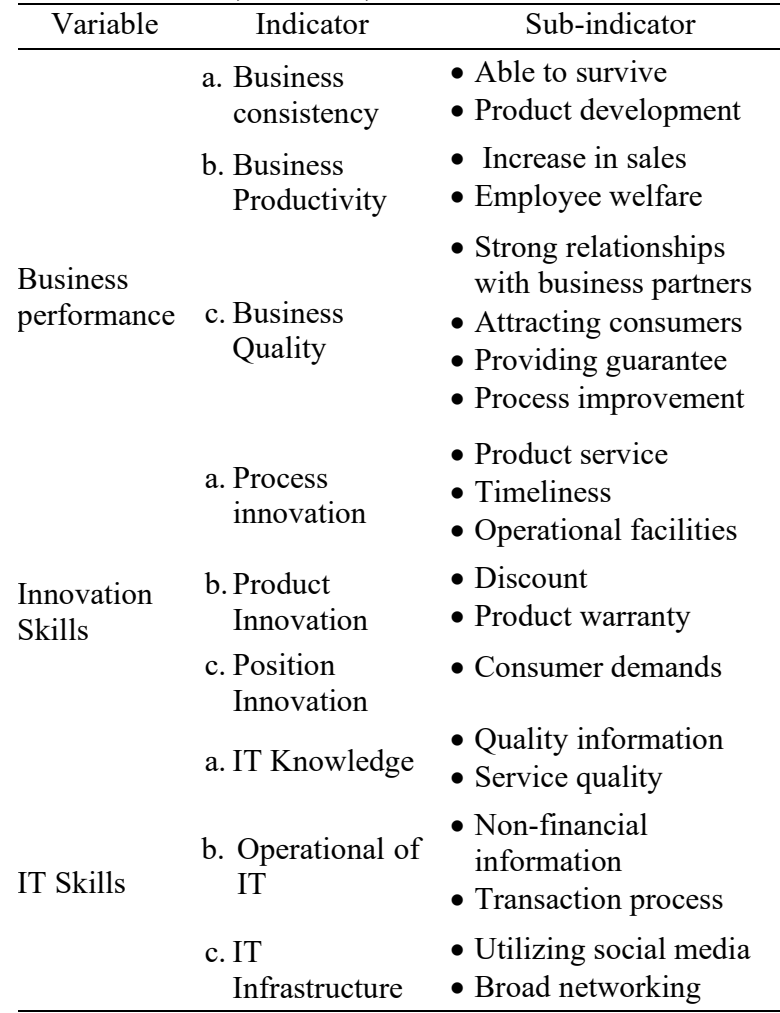

Further, the data were analyzed using descriptive statistical analysis and correlational and regression analysis. Before performing the regression analysis, the requirement analysis encompassing normality, heteroscedasticity, autocorrelation, and multi-collinearity test, was conducted.

Table 4. Results of Instrument Validity and Reliability Test of Variable $\mathrm{Y}, \mathrm{X}_{1}$, and $\mathrm{X}_{2}$

\begin{tabular}{|c|c|c|c|c|}
\hline Variable & $\begin{array}{c}\text { Numbers } \\
\text { of } \\
\text { Valid } \\
\text { Item }\end{array}$ & $\begin{array}{c}\mathrm{R}- \\
\text { count } \\
\text { value } \\
\text { r-count } \\
> \\
0.361\end{array}$ & $\begin{array}{l}\text { Reliability } \\
\text { Coefficient }\end{array}$ & Description \\
\hline $\begin{array}{l}\text { Business } \\
\text { performance } \\
\text { (Y) }\end{array}$ & 8 & $\begin{array}{l}0.561 \\
\text { to } \\
0.800\end{array}$ & 0.85 & $\begin{array}{l}\text { Valid and } \\
\text { reliable }\end{array}$ \\
\hline $\begin{array}{l}\text { Innovation } \\
\text { skills }\left(X_{1}\right)\end{array}$ & 6 & $\begin{array}{l}0.583 \\
\text { to } \\
0.897\end{array}$ & 0.88 & $\begin{array}{l}\text { Valid and } \\
\text { reliable }\end{array}$ \\
\hline IT skills $\left(\mathrm{X}_{2}\right)$ & 6 & $\begin{array}{l}0.717 \\
\text { to } \\
0.861\end{array}$ & 0.89 & $\begin{array}{c}\text { Valid and } \\
\text { reliable }\end{array}$ \\
\hline
\end{tabular}

\section{RESULTS AND DISCUSSION}

\section{Characteristics of the Respondents}

Table 5 shows the respondents' characteristics.

\begin{tabular}{|c|c|c|c|}
\hline No & $\begin{array}{c}\text { Characteristics of the } \\
\text { Respondents }\end{array}$ & $\begin{array}{c}\text { Number of } \\
\text { Respondents }\end{array}$ & Percentage \\
\hline \multirow[t]{4}{*}{1} & Age & & \\
\hline & 20 to 29 years & 62 & $35.0 \%$ \\
\hline & 30 to 39 years & 60 & $34.0 \%$ \\
\hline & $\geq 40$ years & 54 & $31.0 \%$ \\
\hline \multirow[t]{3}{*}{2} & $\overline{\text { Sex }}$ & & \\
\hline & Male & 121 & $69.0 \%$ \\
\hline & Female & 55 & $31.0 \%$ \\
\hline \multirow[t]{6}{*}{3} & Educational background & & \\
\hline & $\begin{array}{l}\text { Elementary/junior high } \\
\text { graduates }\end{array}$ & 6 & $4.0 \%$ \\
\hline & Senior high graduates & 118 & $67.0 \%$ \\
\hline & Associate degree (D3) & 10 & $5.0 \%$ \\
\hline & Undergraduate & 18 & $10.0 \%$ \\
\hline & Others & 24 & $14.0 \%$ \\
\hline \multirow[t]{4}{*}{4} & Work experience & & \\
\hline & 1 to 5 years & 70 & $40.0 \%$ \\
\hline & 6 to 10 years & 53 & $30.0 \%$ \\
\hline & $\geq 10$ years & 53 & $30.0 \%$ \\
\hline
\end{tabular}




\section{Descriptive Analysis}

The descriptive analysis results on all three research variables encompass the central tendency and dispersion (i.e., mean, median, mode, standard error of the mean, standard of deviation, variant, range, minimum score, and maximum score). Provided in Table 6 are the details of the data.

Table 6. Description of Data of $\mathrm{Y}, \mathrm{X}_{1}$, and $\mathrm{X}_{2}$ Variable

\begin{tabular}{lrrr}
\hline & $\begin{array}{c}\text { Statistics } \\
\text { Innovation } \\
\text { skills } \\
\left(\mathrm{X}_{1}\right)\end{array}$ & $\begin{array}{c}\text { IT } \\
\text { skills } \\
\left(\mathrm{X}_{2}\right)\end{array}$ & $\begin{array}{c}\text { Business } \\
\text { performance } \\
(\mathrm{Y})\end{array}$ \\
\hline $\mathrm{N} \quad$ Valid Item & 176 & 176 & 176 \\
\multicolumn{1}{c}{ Missing } & 0 & 0 & 0 \\
Mean & 4.4110 & 4.4489 & 4.3778 \\
Std. Error of Mean & .03779 & .03908 & .03926 \\
Median & 4.5000 & 4.5000 & 4.3750 \\
Mode & 5.00 & 5.00 & 5.00 \\
Std. Deviation & .50139 & .51846 & .52081 \\
Variance & .251 & .269 & .271 \\
Range & 2.83 & 2.83 & 2.88 \\
Minimum & 2.17 & 2.17 & 2.13 \\
Maximum & 5.00 & 5.00 & 5.00 \\
Sum & 776.33 & 783.00 & 770.50 \\
\hline
\end{tabular}

The references of mean score describing the variable of business performance $(\mathrm{Y})$, innovation skills $\left(\mathrm{X}_{1}\right)$, and IT skills $\left(\mathrm{X}_{2}\right)$ are represented using the following score ranges:

Score $5.0=$ very high

Score $4.0=$ high

Score $3.0=$ moderate

Score $2.0=$ low

Score $1.0=$ poor

Table 6 reveals that the mean score of the business performance of the SME sellers got 4.3778 , with the error of the mean at 0.32926 . This result clarifies that the business performance of the sellers is in the "high" category; thus, they only need to keep their performance at best to reach the maximum score of 5.0. The mean score of the variable of innovation skills is 4.4110 , with an error of the mean of 0.03779 . Simply put, the category of innovation skills is "high" The mean score of the variable of innovation skills is 4.4489 , with an error of the mean at 0.02550 . For this reason, the category of IT skills is "high".

\section{Requirement Analysis Test}

Requirement analyses, involving normality, heteroscedasticity, auto-correlation, and multicollinearity test, was performed before proceeding to multiple correlation regression analysis. The results of the four tests have met the requirement since the data of the $\mathrm{Y}, \mathrm{X}_{1}, \mathrm{X}_{2}$, and $\mathrm{X}_{2}$ were normally distributed (all data were in the diagonal line). Still, the variant of the data of variable $\mathrm{Y}$ against the variable $\mathrm{X}_{1}$, and $\mathrm{X}_{2}$ does not follow an obvious pattern, thus indicating the absence of heteroscedasticity. Autocorrelation was not identified given the tolerance value of the variable $X_{1}$, and $X_{2}$ was below 1 or the VIF under 10. The $\mathrm{D}-\mathrm{W}$ value ranges from 2 to 4 ; so it is no multi-correlation is detected. The regression analysis results are feasible since the conditions of all four analyses have been met.

\section{Correlational Analysis and Multiple Regression}

Based on the results of the multiple correlational analysis between the three variables, i.e., (Y) with innovation skills $\left(\mathrm{X}_{1}\right)$ and IT skills $\left(\mathrm{X}_{2}\right)$, the multiple correlational value $\mathrm{R}$ scored 0.795 , rounded off to 0.80 (see Table 7). Such a result confirms that the variable $\mathrm{Y}$ simultaneously correlated with the other two variables; the correlation was "positive" and quite "significant". Furthermore, the determinant coefficient value $\left(\mathrm{R}^{2}\right)$ was 0.627 , significant since the value of sig. $\mathrm{F}<0.05(0.00<0.05)$. The result clarifies that innovation skills $\left(\mathrm{X}_{1}\right)$ and IT skills $\left(\mathrm{X}_{2}\right)$ 
simultaneously contributed to business performance $(\mathrm{Y})$ by $62.7 \%$. The rest $37.3 \%$ represented other factors. Table 7 displays the result of multiple correlation analyses and determinant coefficients. The result of ANOVA regarding the correlation of the innovation skills $\left(\mathrm{X}_{1}\right)$ and IT skills $\left(\mathrm{X}_{2}\right)$ with the business performance $(\mathrm{Y})$ can be seen in Table 8 and Table 9.
Table 8. ANOVA ${ }^{\mathrm{a}}$

\begin{tabular}{lrrrrr}
\hline \multicolumn{1}{c}{ Model } & $\begin{array}{r}\text { Sum of } \\
\text { Squares }\end{array}$ & df & $\begin{array}{r}\text { Mean } \\
\text { Square }\end{array}$ & F & Sig. \\
\hline 1 Regression & 29.984 & 2 & 14.992 & 148.343 & $.000^{\mathrm{b}}$ \\
Residual & 17.484 & 173 & .101 & & \\
Total & 47.467 & 175 & & & \\
\hline
\end{tabular}

a. Dependent Variable: Business performance

b. Predictors: (Constant), IT skills, innovation skills

Table 7. Summary ${ }^{\mathrm{b}}$ Model

\begin{tabular}{|c|c|c|c|c|c|c|c|c|}
\hline \multirow[b]{2}{*}{ Model } & \multirow[b]{2}{*}{$\mathrm{R}$} & \multirow[b]{2}{*}{ R Square } & \multirow{2}{*}{$\begin{array}{l}\text { Std. Error } \\
\text { of the } \\
\text { Estimate }\end{array}$} & \multicolumn{4}{|c|}{ Change Statistics } & \multirow[t]{2}{*}{ DW } \\
\hline & & & & F Change & df1 & df2 & $\begin{array}{c}\text { Sig. F } \\
\text { Change }\end{array}$ & \\
\hline 1 & $.795^{\mathrm{a}}$ & .632 & .3179 & 148.343 & 2 & 173 & .000 & 2.06 \\
\hline \multicolumn{9}{|c|}{ a. Predictors: (Constant), IT skills, innovation skills } \\
\hline
\end{tabular}

Table 9. Coefficients ${ }^{\mathrm{a}}$

\begin{tabular}{|c|c|c|c|c|c|c|c|c|}
\hline \multirow{2}{*}{\multicolumn{2}{|c|}{ Model }} & \multicolumn{2}{|c|}{$\begin{array}{l}\text { Unstandardized } \\
\text { Coefficients }\end{array}$} & \multirow{2}{*}{$\begin{array}{c}\text { Standardized } \\
\text { Coefficients }\end{array}$} & \multirow[t]{2}{*}{$\mathrm{t}$} & \multirow[t]{2}{*}{ Sig } & \multicolumn{2}{|c|}{ Collinearity Statistics } \\
\hline & & $\mathrm{B}$ & Std. Error & & & & Tolerance & VIF \\
\hline \multirow[t]{3}{*}{1} & (Constant) & .529 & .226 & & 2.33 & .02 & & \\
\hline & Innovation Skills & .341 & .069 & .329 & 4.93 & .00 & .479 & 2.09 \\
\hline & IT Skills & .527 & .067 & .524 & 7.86 & .00 & .479 & 2.09 \\
\hline
\end{tabular}

Based on the above results of the multiple regression coefficients in Table 9, a model of multiple linear regression model describing the significance of innovation skills $\left(\mathrm{X}_{1}\right)$ and IT skills $\left(\mathrm{X}_{2}\right)$ to business performance $(\mathrm{Y})$ is provided below.

$$
\mathrm{Y}=\mathbf{0 . 5 2 9}+\mathbf{0 . 3 4 1} \mathrm{X}_{1}+\mathbf{0 . 5 2 7} \mathrm{X}_{2}
$$

The significance test result on regression constants reveals that $\mathrm{a}=0.529$, with the sig value of 0.021 (see Table 9.), falling under the 'significant' category since sig. $<0.05(0.021<$ 0.05 ). Simply put, the constants $\mathrm{a}=0.529$ model significantly contributes to the business attainment of the SMEs in the research site. The result of significance test on regression $\mathrm{X}_{1}$ is $\mathrm{b}=$ 0.341 , with the sig value of 0.005 (see Table 9.), categorized 'significant' given that sig $<0.05$ $(0.000<0.05)$. By that, the variable $\mathrm{X}_{1}$ significantly contributes to the business performance of the SMEs (Y). The result of significance test on regression $\mathrm{X}_{2}$ is $\mathrm{c}=0.527$, with the sig value of 0.005 (see Table 9), 'significant' category, since sig $<0.05(0.000<$ $0.05)$. Such a result clarifies the significance of variable $X_{2}$ to the business performance of the SMEs (Y). The variable of IT skills (X2) is more impactful to the business performance rather than innovation skills (X1), as $0.527>0.341$.

Further, the significance test result on the multiple regression analysis is $\mathrm{Y}=0.529-0.341$ $\mathrm{X}_{1}+0.527 \mathrm{X}_{2}$, 'significant' category due to the fact that sig $0.000<0.05$, is lower than 148.343 (see Table 8.). This result signifies that the model $\mathrm{Y}=0.529+0.341 \mathrm{X}_{1}+0.527 \mathrm{X}_{2}$ is significant and applicable to determine the performance of SMEs in Pasar Glodok using the data of $\mathrm{X}_{1}$ and $\mathrm{X}_{2}$ if all of the independent variables have been 
identified. The multiple linear regression model $\mathrm{Y}=0.529+0.341 \mathrm{X}_{1}+0.527 \mathrm{X}_{2}$ emphasizes that the performance of the SMEs in the research site is in the poor category (score below 1, from the range of 1 to 5) if innovation skills and IT skills are absent. IT skills are also significantly impactful on the business performance of the selected SMEs; the significance value measures at 0.527 (compared to the innovation skills at $0.341)$.

Results of the descriptive analysis revealed that the average score of the business performance of the research subject measures is 4.3778, a good category. This indicates that the merchants at Pasar Glodok, despite their educational background, are competent entrepreneurs. Another point worth mentioning is that the SME owners' innovation skills and IT skills are in the high category, scoring at 4.4110 and 4.4489, respectively. In other words, the innovation skills and IT skills of the research subjects are in the high category since their score ranges from 4.00 to 4.50 . Such indicates that the merchants adapt to the changes in the business.

Results of the multiple correlational analysis between the three variables, i.e., (Y) with innovation skills $\left(\mathrm{X}_{1}\right)$ and IT skills $\left(\mathrm{X}_{2}\right)$, the multiple correlational value $\mathrm{R}$ scored 0.795, rounded off to 0.8 (see Table 7). This is in line with the one seen in Nimlaor et al. [5] that sustainable and innovative development, efficient production, and marketing operation through technology are central to enhancing SMEs' performance. The present study finds that the determinant coefficient $\left(\mathrm{R}^{2}\right)$ of the correlation between innovation and IT skills with the business performance measures at 0.632 ; thus, $63.2 \%$ of the performance of SMEs in Pasar Glodok was determined by the two factors previously mentioned. Such corresponds with the study by Rahman et al. (2016: 510). According to Taneo et al. [19] interestingly, innovation is not the only key to business success; other factors, e.g., hard work and continuous evaluation and improvement, should also be taken into account to attain maximum outputs. Taneo et al. [19] argue that being innovative is necessary for enhancing the competitiveness of SMEs, specifically in the food business.

The present work proposes a model that can be used to predict the maximum performance attainment of SMEs: $\mathrm{Y}=0.529+0.341 \mathrm{X}_{1}+$ $0.527 \mathrm{X}_{2}$ (Y: SMEs Performance; $\mathrm{X}_{1}$ : innovation skill; $\mathrm{X}_{2}$ :IT skills). The notion that IT skills are more impactful on the business attainment of SMEs compared to innovation skills is in line with a study by Ramdan [20]; further Ramdan claims that digital literacy or ICT and development of a digital environment in SMEs is central to the application of digital platform by SMEs in Malaysia. Two factors are central to SMEs' technology adoption: (a) internal factors (e.g., commitment and decision of SME owners or top management; providing adequate funds for human resources development and provision of the digital application needed for the business) and (b) external factors (e.g., competitive atmosphere in the sector of SMEs, supports from the government, consumers and suppliers, and IT consultants in the management of SMEs). Budiningsih et.al [21] explained that the Human Resources competencies of information system managers are a very strategic factor, therefore information technology managers are advised to always improve competencies in the IT field both concerning knowledge, skills, and attitudes in managing IT. Lubis \& Junaidi [22] recommend that strategies to accelerate the adoption of IT use are: (a) Provision of IT infrastructure; (b) Provision of experts in the IT field; (c) Initial capital for IT development; (d) Socialization of IT Benefits in MSME Business Development.

Ghobakhloo et al., as cited in Saleh \& Hadiyat [23] explained that competitive and market globalization has urged businesspeople to create innovation, develop new products or 
services, or apply innovative procedures in their business for optimum performance, specifically SMEs. Winawod et al. [24] revealing that business risks are insignificant to business performance because business performance is determined by the innovation of a product; and Budiningsih et.al [25] explains that innovation is an entrepreneurship function which established either by a business organization, public service organization (government), or individuals/groups

\section{CONCLUSION}

The conclusion of this research is as follows. (a) Innovation skills and IT skills of SME owners are central to optimum performance attainment. (b) Innovation skills and IT skills simultaneously contribute to the business performance; both skills positively and significantly correlated to the business performance with the correlational coefficient $\mathrm{R}=$ 0.8 . The model used to measure the attainment of business performance is $\mathbf{Y}=\mathbf{0 . 5 2 9}+\mathbf{0 . 3 4 1} \mathrm{X}_{\mathbf{1}}+$ $\mathbf{0 . 5 2 7} \mathbf{X}_{2} \quad\left(\mathrm{Y}\right.$ : business performance; $\mathrm{X}_{1}$ : innovation skill; $\mathrm{X}_{2}$ :IT skills); (c) Innovation and information technology skills contribute to the performance attainment of SME entrepreneurs in the research site by $63.2 \%$; the remaining $36.8 \%$ is determined by factors not included in the study. (d) Information technology skills are more impactful than innovation skills in actualizing the performance attainment of SME entrepreneurs $(0.527>0.341)$. (e) For better performance of the SME entrepreneurs, sustainable approaches in fostering innovation and information technology capabilities are essential for candidate entrepreneurs/new entrepreneurs neither in the labor market. The results of research in the industry may be published in schools to bring the concept of link \& match between educational institutions with industry. This study has potential limitations, one example is that the focus is only examining SMEs in one research site, i.e., Pasar
Glodok, Jakarta; on that ground, it is recommended to perform research on other SMEs in other areas using questionnaires in this research, although the characteristics of SMEs are relatively similar.

The contribution of SMEs to the economic growth of a country is undoubtedly and is a medium for beginners to start a business. The results of this study show that in the digital era the prospective entrepreneurs/new entrepreneurs must have sufficient innovation ability and access to information technology because both of them can predict optimal business performance. High innovation capabilities and high access to information technology of prospective SMEs entrepreneurs/new entrepreneurs, will predict a contribution of $63 \%$ business performance optimally. The results of this study may recommend the importance of providing innovation capabilities and access to information technology early and continuously at all levels of education, especially in vocational-based schools.

\section{REFERENCES}

[1] Badan Pusat Statistik Indonesia, "Berita Resmi Statistik No.37/05/Th. XXIV, 05 Mei 2021: Keadaan Ketenagakerjaan Indonesia Februari 2021,”2021.

[2] Binus University Bandung, "Peran UMKM Dalam Perekonomian Indonesia," Creativepreneurship Binus University Bandung, 2020.

[3] J. G. V. Hernández and V. Y. V Lerma, "Impact of business performance and TQM on the SMEs of Mexico," Manag. Perspect., vol. 3, no. 2, pp. 1-17, 2017.

[4] S. Zulkiffli and N. Perera, "A literature analysis on business performance for SMES - subjective or objective measures?," Sydney Bus. Sch. Pap., pp. 1-9, Jan. 2011, doi: 10.2139/ssrn. 1867874 . 
[5] C. Nimlaor, J. Trimetsoontorn, and W. Fongsuwan, "Factors affecting business performance: An empirical study in Thailand," Res. J. Bus. Manag., vol. 8, no. 2, pp. 89-103, 2014, doi: 10.3923/RJBM.2014.89.103.

[6] W. A. Khan, R. A. Hassan, M. Z. Arshad, and U. Kashif, "Does innovation affect the firm performance in developing countries? a conceptual framework," J. Pengur., vol. 59, pp. 1-13, Sep. 2020, Accessed: Oct. 10, 2021. [Online]. Available: http://ejournal.ukm.my/pengurusan/article/ view/34675.

[7] L. E. Sudiarta, I. K. Kirya, and I. W. Cipta, "Analysis of factors affecting the performance of small and medium enterprises (MSMEs) in Bangli regency," J. Manajemen, e-Journal Bisma Univ. Pendidik. Ganesha, vol. 2, pp. 1-8, 2014.

[8] N. Oza and M. Mehta, "A study of ICT skills and competencies essential for corporate LIS professionals," Int. J. Res. Anal. Rev., vol. 5, no. 4, pp. 596-603, 2018.

[9] K. M. Ku Bahador and A. Haider, "Information technology skills and competencies - a case for professional accountants," Lect. Notes Bus. Inf. Process., vol. 127 LNBIP, pp. 81-87, 2012, doi: 10.1007/978-3-642-34228-8_9.

[10] S. Fauzia, I. Budiningsih, A. Djaelani, and M. Ahmad, "Dominant factors affecting the behavior of innovative employees," Polish J. Manag. Stud., vol. 16, no. 1, pp. 32-40, 2017, doi: 10.17512/PJMS.2017.16.1.03.

[11] J. Barrand, P. Y. Sanseau, and G. Ferrante, "The Leader-Member Relationship at the Core of Innovation Development: Member Perceptions, Positions and Expectations," in Knowledge Perspectives of New Product Development: A Comparative
Approach, D. G. Assimakopoulos, E. G. Carayannis, and R. Dossani, Eds. New York: Springer, 2012.

[12] I. Budiningsih, T. D. Soehari, and J. Leonard, "Dominant factors influence the behavior to produce innovative products," China-USA Bus. Rev., vol. 17, no. 9, pp. 453-461, 2018, doi: 10.17265/15371514/2018.09.002.

[13] G. Andri, W. R. Adawiyah, R. Purnomo, and Z. Sholikhah, "The Minang - nomads businesses' performance: the role of proactive personality, creativity and innovative work behavior," $J$. Pengur., vol. 58, no. 0, Jun. 2020, Accessed: Oct. 10, 2021. [Online]. Available: http://ejournal.ukm.my/pengurusan/article/ view/31805.

[14] I. Budiningsih, H. Sukamto, and S. Mujiani, "Dominant determinant characteristics of innovative behavior of new entrepreneur candidates," Manag. Sci. Lett., vol. 11, no. January, pp. 1-7, 2021, doi: 10.5267/J.MSL.2021.1.022.

[15] J. Tidd and J. Bessant, Managing Innovation, Integrating Technological, Market and Organizational Change, 4th Editio. England: John Wiley \& Sons, Ltd, 2019.

[16] M. Rifqy, R. Purwo, A. Wibowo, and A. Widiastuti, "Analisis tingkat penggunaan teknologi informasi dan komunikasi pada usaha kecil menengah di Kab. Jepara," $J$. Din. Ekon. Bisnis, vol. 9, no. 2, pp. 89104, 2012.

[17] United Nation, United Nations Competency Development - A Practical Guide. New York: United Nations, Human Resources Management, 2010.

[18] S. Pérez-López and J. Alegre, "Information technology competency, knowledge processes and firm performance," Ind. Manag. Data Syst., 
vol. 112 , no. 4, pp. 644-662, 2012, doi: 10.1108/02635571211225521.

[19] S. Y. M. Taneo, E. A. Setiyati, and D. Stephanus, "Innovation and economic behavior of chinese ethnic entrepreneurs in improving competitiveness of small and medium scale food industry," 2013.

[20] M. R. Ramdan, N. L. Abdullah, R. M. Isa, and M. H. Hanafiah, "Meneroka faktorfaktor yang mempengaruhi penggunaan platform digital oleh perusahaan mikro dan kecil (Exploring factors influencing the use of digital platform by micro and small enterprises)," J. Pengur. , vol. 59, pp. 1-17, Sep. 2020, Accessed: Oct. 10, 2021. [Online]. Available: http://ejournal.ukm.my/pengurusan/article/ view/38617.

[21] I. Budiningsih, T. D. Soehari, and I. Irwansyah, "Dominat factor for improving information security awareness," Cakrawala Pendidik., vol. 38, no. 3, pp. 490-498, Oct. 2019, doi: 10.21831/cp.v38i3.25626.

[22] T. A. Lubis and Junaidi, "Pemanfaatan teknologi informasi pada usaha mikro kecil dan menengah di kota Jambi," $J$. Perspekt. Pembiayaan dan Pembang. Drh., vol. 3, no. 3, pp. 163-174, 2016.

[23] B. Saleh and Y. D. Hadiyat, "Penggunaan teknologi informasi di kalangan pelaku usaha mikro kecil menengah di daerah perbatasan," J. Pekommas, vol. 1, no. 2, pp. 141-152, Oct. 2016, doi: 10.30818/JPKM.2016.2010204.

[24] N. A. Winawod, J. L. Sepang, and H. N. Tawas, "The influence of innovation and courage to take on product performance with the intensity of competition as a moderating variable," J. EMBA, vol. 6, no. 4, pp. 2908-2917, 2018.

[25] I. Budiningsih, S. Fauzia, and A. Djaelani, Innovative Employee. Mauritius: Lap Lambert Academic, 2018. 